\title{
РЕЦЕНЗИЯ \\ на монографию В.П. Воробьева \\ «Высшие органы власти Государства Израиль»
}

\section{Денисов В.И.*}

Один из известных российских специалистов в области конституционного права В.П. Воробьев, имеющий большой опыт дипломатической работы на Ближнем Востоке, продолжает активно разрабатывать вопросы, связанные со становлением и развитием израильской политической и конституционно-правовой системы. В вышедшей недавно его новой монографии «Высшие органы власти Государства Израиль» автор с присущей ему последовательностью и доказательностью исследует правовой статус и функционирование высших органов власти страны - Кнессета, правительства, президента и Верховного суда.

Анализ вопросов, относящихся к деятельности Кнессета, ведется параллельно с рассмотрением избирательной системы Израиля, правовую основу которой, как справедливо указывает автор, составляют несколько законодательных актов. Рассматривая эту систему, автор выделяет ее важный положительный аспект - широкую представительность израильского избирательного корпуса, который формируется на основе пропорциональной системы голосования.

В работе отмечается, в частности, уникальный характер системы высших органов власти в Израиле, при которой парламент и глава правительства избираются прямым голосованием, анализируется проблема взаимоотношений между ними. При этом важно иметь в виду, что Кнессет путем вотума недоверия правительству может отправить в отставку и премьер-министра, избранного всеобщим голосованием, что, в общем-то, не характерно для взаимоотношений законодательной и исполнительной ветвей власти, например, государств с президентской формой правления. Весьма интересна характеристика действующей в Израиле системы правления. Эта система получила в научной литературе название «президентарной», т.е. смешанной модели президентско-парламентского типа.

- Денисов Валерий Иосифович - д.и.н., к.ю.н., Чрезвычайный и Полномочный Посол, профессор. 
Особого внимания заслуживает представленный анализ деятельности механизма исполнительной власти Израиля. В частности, приводятся интересные суждения израильских государствоведов о развитии парламентаризма в стране, его этапах - от гегемонии одной партии и противостояния двух крупнейших партий до начала становления партийного полиморфизма.

Прямое избрание премьер-министра автор квалифицирует, и с этим нельзя не согласиться, как «настоящую конфискацию суверенитета Кнессета политическими партиями». Принятие Основного закона о правительстве 1992 года, который ввел прямые выборы главы правительства, несомненно, усилило его правовое положение. Так, предоставление всенародно избранному премьеру права, с согласия президента, досрочно распускать парламент (Кнессет) - убедительный пример особой значимости поста главы правительства в израильском государстве. Подобная практика, как известно, не имеет аналогов в мире. Действительно, в израильской государственно-правовой системе сложилась уникальная и отчасти парадоксальная ситуация, при которой правительство де-факто имеет приоритет в системе высших органов власти. Такая ситуация в конце концов была исправлена 7 марта 2001 года, когда Кнессет принял новый, третий по счету за всю историю страны, Основной закон о правительстве, по которому отменяются прямые выборы премьер-министра. Этот законодательный акт начнет действовать с 2003 года и, судя по всему, израильскую конституционную систему ждут, в недалеком будущем, серьезные трансформации.

Автор дает глубокий анализ правового положения института президентства в Израиле. Статус президента формировался, как справедливо считает В.П. Воробьев, постепенно и последовательно. Весьма примечательно и то, что глава государства не входит ни в одну из ветвей власти. Его полномочия сокрашены, что, как подчеркивается в монографии, привело к «разбалансировке в системе государственно-правовых институтов власти». Здесь нельзя не согласиться с выдвинутым исследователем тезисом о том, что потеря президентом важных полномочий лишает его присущего права быть «высшим» арбитром в израильской политической жизни.

Специальная глава работы посвящена месту и роли Верховного суда в государственно-правовой системе и политической жизни Израиля. Автор, глубоко анализируя судебную практику, отмечает, что в усло- 
виях отсутствия в стране писанной Конституции и Конституционного суда Верховный суд не только защищает основополагающие демократические ценности, права и свободы человека, но и выполняет контрольные функции, являясь «высшим судом справедливости». Фактически Верховный суд в этом качестве постепенно превращается, как отмечается в монографии, в орган конституционного надзора.

По мнению В.П. Воробьева, в сфере правосудия в Израиле сложилась достаточно своеобразная ситуация, при которой решения высших органов государственной власти и управления фактически контролируются Верховным судом, что, естественно, усиливает его роль и влияние в правовой жизни страны. Это чревато нарушением равновесия во всей системе высших органов власти и управления, в случае, если подобная тенденция сохранится. А это, в свою очередь, может привести к эрозии политической системы (правда, автор избрал здесь довольно нейтральный термин «модификация» политсистемы, с чем вряд ли можно согласиться).

Подводя итог монографического исследования, В.П. Воробьев делает, как представляется, верный прогноз о том, что политическая «элита Израиля в самом ближайшем будушем усилит внимание к происходящим в стране политико-правовым процессам». Вполне очевидно, что в настоящее время в Израиле назрела необходимость модернизации правого положения основных государственно-правовых институтов, дальнейшего укрепления демократических начал в их деятельности.

В.П. Воробьев подготовил, на наш взгляд, серьезную и очень нужную работу, которая по праву займет достойное место среди новейших исследований, посвященных современному состоянию конституционного права зарубежных государств. Она, безусловно, будет полезна и востребована как научными сотрудниками, так и специалистамипрактиками, в том числе в целях более глубокого понимания сложившейся на сегодняшний день драматической и напряженной ситуации на Ближнем Востоке. 